\title{
Plant Succession on Tundra Mudflows: Preliminary Observations
}

\author{
J. D. H. LAMBERT ${ }^{1}$
}

\begin{abstract}
Tundra mudflows are one of the characteristic features of arctic slopes with unstable soils. They generally occur during the early part of the thaw period, but may occur after a heavy rainfall. Only two relatively short-lived vegetation elements were evident and both are characteristic of disturbed sites. Islands of vegetation and soil of the type that dominate the slope before the mudflow are left scattered within the flow lines. Once a turf of grasses, sedges and herbs has formed the island vegetation is able to colonize the turf mat. Areas where previous mudflows have occurred are clearly recognizable both by a long depression parallel to the direction of the slope and terminal fan of debris. Detailed studies on such naturally-occurring phenomena would be of great value in view of increased use of heavy vehicular equipment by the oil and mining companies in the Canadian North.
\end{abstract}

RÉSUMÉ. La succession des plantes sur Les coulées boueuses: observations préliminaires. Les coulées boueuses sont une des caractéristiques des pentes arctiques à sols instables. Elles se produisent généralement au début de la période de dégel, mais peuvent aussi se produire après une forte pluie. Seuls deux éléments éphémères de végétation sont en évidence et tous deux sont caractéristiques de sites perturbés. Des îlots de végétation et de sol du type qui dominait la pente avant la coulée sont laissés épars à l'intérieur des lignes de coulée. Lorsqu'un gazon de graminées, de laîches et d'herbages s'est formé, l'îlot de végétation peut alors coloniser ce gazon. Les zones d'anciennes coulées sont clairement reconnaissables aussi bien par une longue dépression parallèle à la direction de la pente que par un cône de débris. Des études détaillées de ces phénomènes naturels seraient d'une grande valeur en regard de l'utilisation accrue de véhicules lourds par les compagnies minières et pétrolières dans le Nord canadien.

\begin{abstract}
РЕЗЮМЕ. Предварителъные данные о смене растительности на арязевых потоках в тундре. Грязевые потоки являются в Арктике одной из характерных черт склонов с неустойчивыми грунтами. Они обычно встречаются в ранние периоды таяния, но могут также появиться после проливных дождей. Ясно пока только наличие двух короткоживущих растительных элементов, присущих участкам с нарушенной почвой. Островки растительности и почвы, которыс доминировали на данном склоне до образования грязевото потока, остаются рассеянными между полосами размытого грунта. Плоцадки, где грязевые потоки были ранее, обычно ясно различимы как по длинным впадинам параллельным направлению склона, так и по оконечным конусам наносов. Детальное исследование таких естественно обравовавшихся участков почвы имеет большое значение ввиду нарастағпего использования тяжелых транспортных механизмов нефте- и горнодобывающими компаниями, ведущими изыскания на севере Канады.
\end{abstract}

\section{INTRODUCTION}

The effects upon vegetation of frost action in soil in arctic regions have long been recognized (Sigafoos 1951). Tundra mudflows are one of several microrelief features described by Sigafoos and Hopkins (1952) as characteristic of arctic slopes with unstable soil. A detailed study by Rapp (1960) dealing with

\footnotetext{
${ }^{1}$ Department of Biology, Carleton University, Ottawa, Canada.
} 
geomorphic development of mountain slopes gives well documented evidence to suggest that mudflows (bowl slides) are associated with prolonged, unusually heavy precipitation. Observations reported in this paper are a by-product of a detailed study (Lambert 1968) on the ecology and successional trends of tundra plant communities in the low arctic, sub-alpine zone of the Richardson Mountains, Northwest Territories, and British Mountains, Northern Yukon Territory.

Recent and past mudflows are readily definable on the slopes bordering Canoe Lake, 23 miles due west of Aklavik $\left(68^{\circ} 04^{\prime} \mathrm{N}\right.$., $135^{\circ} 30^{\prime} \mathrm{W}$.), and on slopes bordering pre-existing drainage pathways. They rarely occur on slopes away from lakes and drainage pathways. Mudflows tend to occur on sloping surfaces where the active layer is thick and silt-rich soil overlain by peat and turf predominate. Under such conditions drainage is impeded by the vegetation as well as by permafrost. During the summer of 1966 considerably more rain fell in the Canoe Lake area than had fallen the previous summer. In 1965 only two days of light rain were recorded; in 1966 between July 18 and 29 over 8 inches were collected in a canoe at the lake (admittedly not an ideal rain gauge, but a good indication of the amount of precipitation). Within the same period, records kept by the Meteorology Branch of the Canada Department of Transport (1966) show 1.28 inches were recorded at Inuvik and 0.61 inches at Shingle Point. Several mudflows occurred during the latter part of the 1966 summer. The following summer (1967) additional mudflows were evident in the Canoe Lake area suggesting heavy rain can and did have both an immediate as well as a delayed effect on mass surface movement.

Heavy rains were experienced in the Canoe Lake area during the summer of 1971. New mudflows were evident in August (Kerby, personal communication).

It would appear evident, although studies are needed, that during relatively dry summers ground water is depleted; during moist summers storage is increased. Such storage probably effects carry-over of some precipitation from one year to the next. Conditions would therefore approximate those described by Rapp (1960) in Scandinavia.

\section{RESULTS AND DISCUSSIONS}

Six old mudflow sites bordering Canoe Lake were studied on the basis of vegetation composition; random measurements to determine thickness of active layer were also made in the 6 sites. Three sites are believed to be of recent origin, the ages of the other three are unknown and would be purely speculaiive. Several other mudflow sites were observed. A 10 sq. m. (1.2 sq. yard) quadrat was placed within each identifiable vegetation type. Species presence was recorded along with a subjective estimate of per cent coverage. The occurrence of tundra mudflows on the slopes bordering Canoe Lake (elevation 1,050 feet) can probably be related to the position of the two major plant communities (Lambert 1968). The climax vegetation on mesic slopes (inclination 10 degrees between 1,100-1,525 feet) is dominated by Betula glandulosa and Vaccinium uliginosum. The active layer is relatively deep, up to 3 feet. The soil profile has a thin organic layer ( 3 inches) overlying a thick mineral layer. At lower elevations the slopes are 

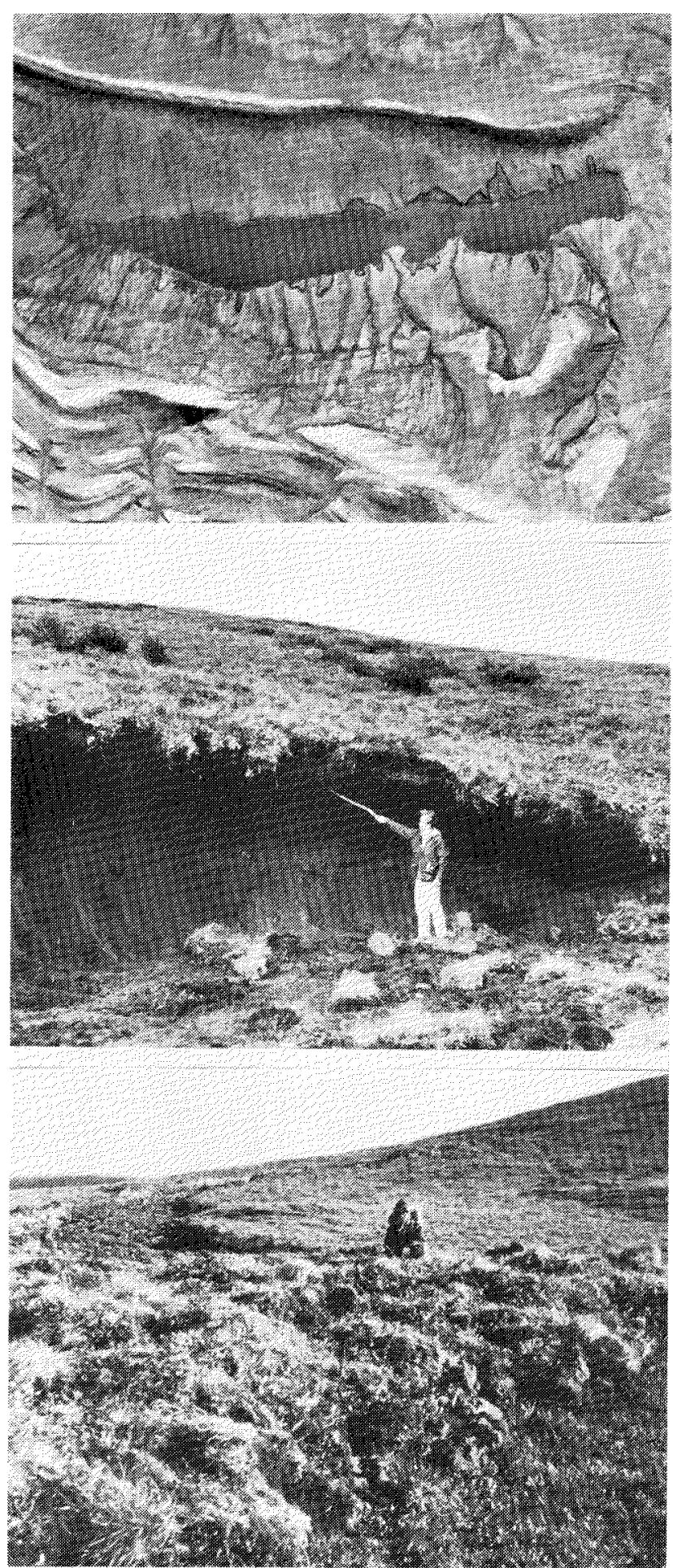

FIG. 1. Mudflows are apparent as the outlined darker grey areas, Canoe Lake, Richardson Mountains.

FIG. 2. Massive mudflow scar on slope at approx. 1,400 feet south of Canoe Lake. End of stick indicates surface of permafrost table. (Photo by Krajina).

FIG. 3. Irregular mounds of soil and vegetated turf at base of slope where flow stops. (Photo by Krajina). 
dominated by Betula glandulosa and the hummock forming Eriophorum vaginatum (elevation 1,080-1,150 feet). The permafrost table in this community is close to the surface and uneven (average thickness of active layer is 6 to 18 inches), restricting rapid subsurface drainage from further up slope.

Intensive differential frost heaving in the saturated soils of the climax community in autumn may possibly tear the densely interwoven root mass apart so that a mass movement of fluid materials can flow down slope the following spring. Surface cracks have been observed, 1 foot in width and up to 30 feet in length, across the slope. The taut roots of the vegetation on either side of the cracks would appear to play a role in holding the down slope vegetation and soil in place.

Tundra mudflow macrorelief can be recognized on aerial photographs (Fig. 1). It consists of semi-circular depressions, up to 10 feet deep, at the scar face (Fig. 2) and merges down slope into hummock fan-like convexities (Fig. 3). The scars can extend from a few feet to several hundred yards parallel to the direction of the slope. Islands of tundra vegetation are left scattered about the upper portion of the mudflow site below the original break (Fig. 4). That vegetation has both a direct and indirect influence on the permafrost by its thermal properties has been documented by many authors and has been reviewed by Brown (1963). The loss of the vegetative cover leads to an initial rapid thawing of the permafrost surface. The average thickness of the active layer under the climax association was never greater than 36 inches. On exposed sites, such as mudflows, the active layer was always greater than 35 inches but rarely exceeded 50 inches. The thawing of the exposed permafrost and seepage from the exposed scar keep the silty soil saturated for several years. Probes to determine depth of thaw directly below the scar suggest that thawing is greatest at this point. The disturbed nature of the site (the water-logged condition of the exposed mineral soil and the low percentage vegetation cover) results in a deeper penetration of thaw, between 40 and 50 inches. It is further suggested that as a result of the disturbance and increased depth of thaw a depression forms in the permafrost table just below the scar face (Fig. 5). Further down slope from the scar, because of the increased density of vegetation, the depth of thaw is not greatly increased.

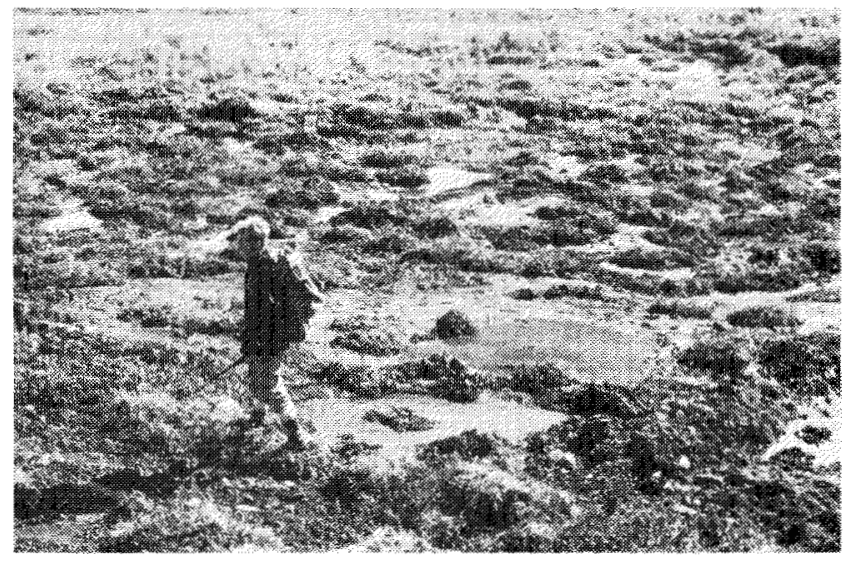

FIG. 4. Area immediately below mudflow scar. Isolated islands of vegetation are left during the down slope movement of the fluid soil. Waterlogged exposed silty soil dominates the area. (Photo by Krajina). 


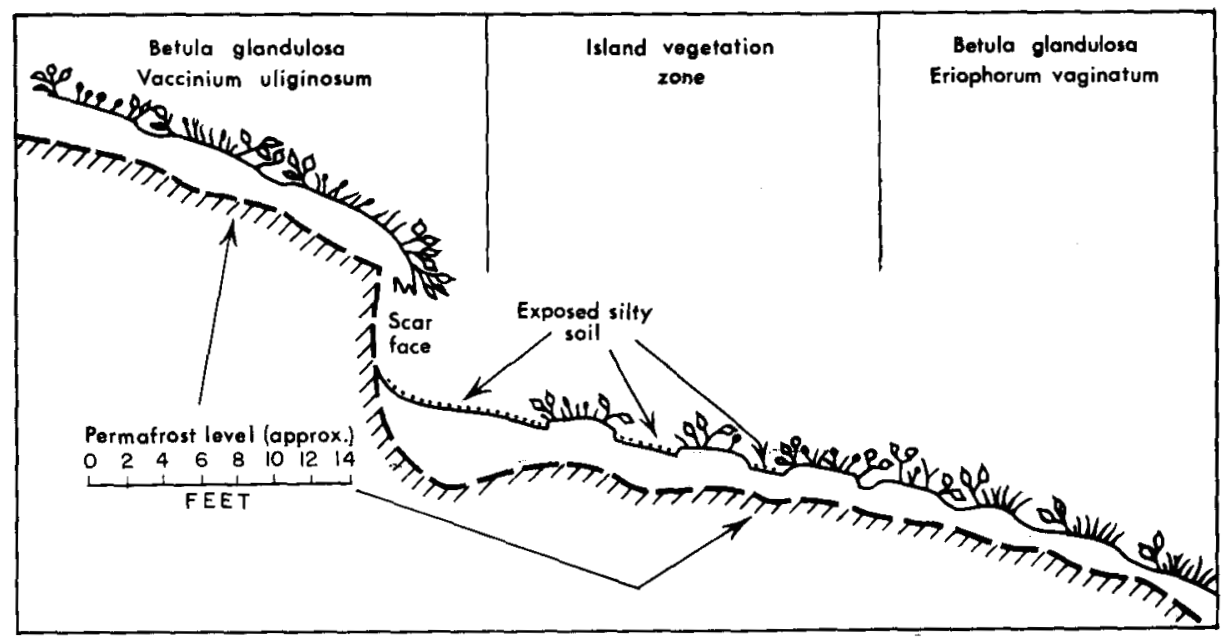

FIG. 5. Distribution of plant communities above and below mud slump scar, indicating approximate permafrost depth.

Kerfoot (1969) suggests that the critical factor influencing the longevity of mud slumps is the maintenance of fresh exposures of substrate with a high ice content. It is suggested here that as the exposed permafrost at the scar thaws, the overhanging vegetation slowly collapses over the scar and further seepage is impeded. At this point any further recession of the mudflow virtually ceases and exposed silty soil can support a greater density of pioneer species. It is to be expected as Brown (1963) has suggested that the thickness of the active layer will in time be reduced due in part to the effect the colonizing vegetation has on reducing solar radiation and moisture penetration.

Directly below the scar, and between the islands, the exposed silty soil is first colonized by scattered individuals of the annual Senecio congestus and Eriophorum scheuchzeri (Table 1). The exposed soil of the mudfiow is only moderately to slightly acid (pH 5.5 to 6.9) compared to the strongly acid condition of the mineral soil of the surrounding climax community ( $\mathrm{pH} \mathrm{4.6).} \mathrm{It} \mathrm{is} \mathrm{suggested} \mathrm{that}$ seepage from the exposed scar plus the rapid initial thawing of the exposed perma-

TABLE 1.* First stage of plant succession.

\begin{tabular}{|c|c|c|c|}
\hline & \multicolumn{3}{|c|}{$\begin{array}{c}\text { Mud flow sites } \\
\text { (per cent coverage) }\end{array}$} \\
\hline & 1 & 2 & 3 \\
\hline \multicolumn{4}{|l|}{ Vascular plants } \\
\hline $\begin{array}{l}\text { Senecio congestus } \\
\text { Eriophorum scheuchzeri }\end{array}$ & $\begin{array}{r}15 \\
5\end{array}$ & $\begin{array}{l}20 \\
10\end{array}$ & $\begin{array}{l}30 \\
20\end{array}$ \\
\hline \multicolumn{4}{|l|}{ Mosses } \\
\hline $\begin{array}{l}\text { Dicranella subulata } \\
\text { Pohlia } \mathrm{sp}\end{array}$ & - & $\frac{3}{-}$ & $\begin{array}{l}3 \\
3\end{array}$ \\
\hline Per cent bare ground & 80 & 70 & 50 \\
\hline
\end{tabular}

*Tables 1 and 3 represent the same three mudflow sites. 
frost not only keeps the silty soil saturated for several years but at the same time maintains a suitable substrate for the pioneer species. Average coverage of silty soil was estimated at 50 to 80 per cent.

During the following years Calamagrostis canadensis, Arctagrostis latifolia, Equisetum arvense, Petasites frigidus and numerous other species (Table 2) appear in association with the original colonizers on the exposed soil sites. Average per cent coverage of the exposed silty soil in sites 4, 5 and 6 during the second stage of succession was estimated to be between 5 and 25 per cent.

TABLE 2** Second stage of plant succession.

\begin{tabular}{|c|c|c|c|}
\hline & \multicolumn{3}{|c|}{$\begin{array}{c}\text { Mud flow sites } \\
\text { (per cent coverage) }\end{array}$} \\
\hline & 4 & 5 & 6 \\
\hline \multicolumn{4}{|l|}{ Vascular plants } \\
\hline Calamagrostis canadensis & - & 40 & 60 \\
\hline Petasites frigidus & 10 & 10 & 10 \\
\hline Senecio congestus & 25 & 10 & 5 \\
\hline Eriophorum scheuchzeri & 15 & 10 & 10 \\
\hline Salix alaxensis & 5 & 5 & 5 \\
\hline Equisetum arvense & - & 10 & 5 \\
\hline Arctagrostis latifolia & 20 & - & - \\
\hline \multicolumn{4}{|l|}{ Mosses } \\
\hline Dicranella subulata & - & 2 & 3 \\
\hline Aulacomnium turgidum & 2 & $\overline{2}$ & - \\
\hline Trichodon cylindicus & 1 & - & - \\
\hline Harpanthus scutatus & 1 & - & - \\
\hline Per cent bare ground & 25 & 15 & 5 \\
\hline
\end{tabular}

*Presented here are data on the second stage of secondary succession, island vegetation was not sampled. From observations the same major species listed in Table 3 were also presented.

TABLE 3. Island hummock vegetation (major species only).

\begin{tabular}{|c|c|c|c|}
\hline & \multicolumn{3}{|c|}{$\begin{array}{c}\text { Mud flow sites } \\
\text { (per cent coverage) }\end{array}$} \\
\hline & 1 & 2 & 3 \\
\hline \multicolumn{4}{|l|}{ Vascular plants } \\
\hline Betula glandulosa & 25 & 35 & 30 \\
\hline Vaccinium uliginosum & 30 & 30 & 25 \\
\hline Carex lugens & 2 & 20 & 5 \\
\hline Ledum decumbens & 15 & 10 & 5 \\
\hline Vaccinium vitis-idaea & 10 & 15 & 5 \\
\hline Salix pulchra & 10 & 5 & 20 \\
\hline Polygonum bistorta & 2 & 1 & 2 \\
\hline Empetrum hermaphroditum & 5 & 2 & 2 \\
\hline Stellaria longipes & 1 & 1 & 1 \\
\hline \multicolumn{4}{|l|}{ Mosses } \\
\hline Aulacomnium turgidum & 10 & 10 & 5 \\
\hline Hylocomium splendens & - & - & 15 \\
\hline Dicranum elongatum & 15 & $\overline{-1}$ & 5 \\
\hline Rhytidium rugosum & - & 20 & 10 \\
\hline \multicolumn{4}{|l|}{ Lichens } \\
\hline Cetraria cucullata & 5 & 2 & 2 \\
\hline Cetraria islandica & - & 2 & 2 \\
\hline Peltigera aphthosa & 5 & 5 & 5 \\
\hline
\end{tabular}


Species composition of the islands is the typical climax vegetation (Table 3) dominated by prostrate shrubs, ericaceous species, herbs, mosses and lichens.

Snow accumulation in mudflow depressions is deeper resulting in compaction of the taller grasses and herbs each winter. Below the scar, over bare ground, the snow depth in site 2 (28 April 1972) was between 28 and 35 inches and in the grass-dominated area downslope between 10 and 25 inches. On the surrounding undisturbed tundra snow depth ranged from 1 to 10 inches depending on whether measurements were made on hummocks or in depressions. There is little if any decomposition of organic matter so that in time a turf forms over the exposed soil thereby preventing further erosion (Fig. 6).

With the development of a more suitable and stable substrate the climax vegetation that remains on isolated islands on the silty soil is able to colonize the turf mat and replace the grasses and herbs. The stages of secondary succession appear to be completed in only two steps but probably over a considerable period of time. The re-establishment of the climax vegetations appears to depend on the prior establishment of only two relatively short-lived vegetation elements. They are considered short-lived because both are characteristic of wet disturbed sites and do not form self-perpetuating long-lasting communities in the Canoe Lake area (Lambert 1968). In every case, including sites where species presence was not recorded, the same successional pattern appeared to be followed.

Basically the same pattern of revegetation has been described by Kerfoot (1969) in a maritime environment. Colonization of mud surfaces occurs once the slump becomes inactive. The second stage develops when the exposed soil is no longer subjected to mudflow or deposition by running water. The grass vegetation under maritime conditions was replaced by Salix spp. whereas the old headwall was characterized by a Dryas-hummock community type. In the subalpine region of the Richardson Mountains Salix spp. were not found to dominate the stabilized depression.

The position of every mudflow around Canoe Lake was clearly marked by a long depression and terminal pile of debris on the lake shore. The continued occurrence of such down slope movements could lead to a buildup of lake sediment, possibly cut off drainage outlets and lead, in time, to the obliteration of the lake.

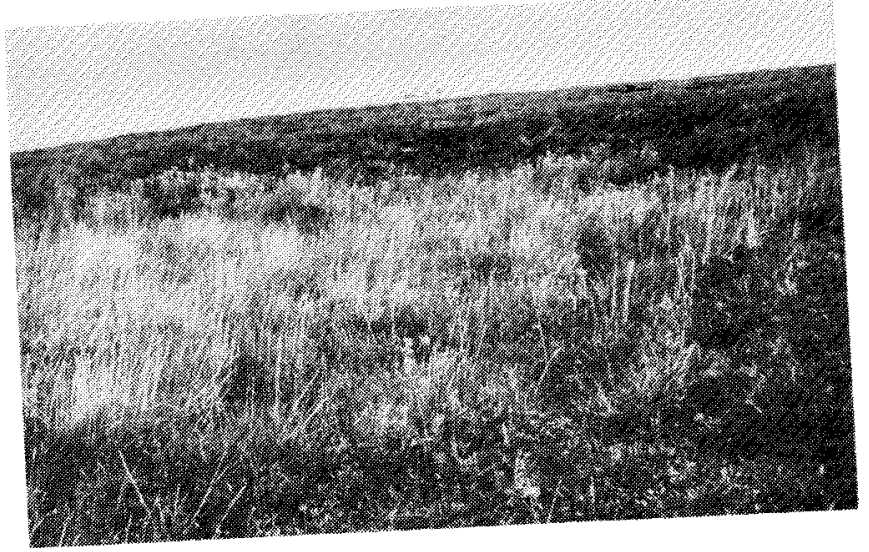

FIG. 6. After one or two years the silty soil is covered by vegetation. On the upper more hydric (seepage) area below the scar, Senecio congestus and Eriophorum scheuchzeri dominate, whereas on the drier areas below Calamagrostis canadensis forms the major cover. (Photo by Lambert). 
Considerable discussion has been generated in recent months concerning increased oil company exploration activity in the Mackenzie Delta, Northwest Territories, and surrounding regions. Seismic operations have been criticized because in some instances vegetation and organic soil has been completely removed exposing the mineral soil either in a frozen or unfrozen state. Dire consequences were predicted because of such disturbance. The recovery of the Imperial Oil 1965 summer seismic lines appears similar in many ways to that of naturally occurring mudflows described by Kerfoot (1969). It would appear that following the disturbance, natural or man-made, there is little if any lateral erosion or widening of the scar or extensive thawing and slumping within the disturbed area. Heat penetration while greater in exposed soil is not so extensive as to cause massive slumping except in isolated cases where segregated ice is present. The low precipitation and the generally low ice content of the soil preclude the possibility of extensive erosion. The depth of the depression in seismic lines can be related to the degree of permafrost degradation (thermokarst subsidence) following the removal of the protective vegetative cover and the establishment of colonizing plants. A future paper supported by quantitative data now being collected on man-made disturbances will discuss this problem in detail.

Of great value now would be a detailed analysis of past naturally-occurring mudflows. Data would then be available on such things as rates of revegetation, community change, soil nutrient change, buildup of permafrost, decrease in thickness of active layer, soil binding qualities of succession plants, water retaining capacities of the exposed soil, ice content of permafrost, etc. From such data simulated models could be derived that would be of great value in predicting not only how man-induced disturbances would recover but also in predicting the possible effects of such disturbances.

\section{ACKNOWLEDGEMENT}

This work was supported by the National Research Council of Canada and the President's Committee on Arctic and Alpine Research, University of British Columbia.

\section{REFERENCES}

BROWN, R. J. E. 1963. Influence of vegetation on permafrost. Lafayetts: Proceedings: Permafrost International Conference. NAS-NRC Publication 1287 pp. 20-25.

CANADA DEPARTMENT OF TRANSPORT. 1960-1966 climatic data from Dew Line stations and Inuvik, N.W.T. Toronto: Department of Transport, Meteorological Branch.

KERFOOT, D. E. 1969. The geomorphology and permafrost conditions of Garry Island, N.W.T. Unpublished Ph.D. Thesis, University of British Columbia. 308 pp.

LAMBERT, J. D. H. 1968. The ecology and successional trends of tundra plant communities in the low arctic subalpine zone of the Richardson and British Mountains of the Canadian western arctic. Unpublished Ph.D. Thesis, University of British Columbia. 164 pp.

RAPP, A. 1960. Recent development of mountain slopes in Karkevagge and surroundings, northern Scandinavia. Geografiska Annaler, 42 (2-3): 65-200.

sigafoos, R. S. 1951. Soil instability in tundra vegetation. Ohio Journal of Science, 51 (6): 281-98.

SIGAFOOS, R. S. and D. M. HOPKINS. 1952. Soil instability on slopes in regions of perenniallyfrozen ground. Frost action in soils: a symposium. Highway Research Board. National Research Council Publication 213, pp. 176-92. 